\title{
Microbial fuel cell-induced production of fungal laccase to degrade the anthraquinone dye Remazol Brilliant Blue R
}

\author{
Marta Filipa Simões ${ }^{1}$. Alfredo Eduardo Maiorano ${ }^{2}$. Jonas Gomes dos Santos ${ }^{2}$ - Luciana Peixoto ${ }^{3}$. \\ Rodrigo Fernando Brambilla de Souza ${ }^{4}$ Almir Oliveira Neto ${ }^{4}$. António Guerreiro Brito ${ }^{5}$. \\ Cristiane Angélica Ottoni ${ }^{2,6,7,8}$ (D)
}

Received: 28 October 2018 / Accepted: 13 March 2019 / Published online: 27 March 2019

(c) Springer Nature Switzerland AG 2019

\begin{abstract}
The anthraquinone dye Remazol Brilliant Blue R is largely used in the textile industry. However, its removal from wastewaters is costly and complex. Many methods have been tested to solve this ecological problem, but there is still a need for efficient methods. We propose here an alternative use of a two-chambered microbial fuel cell (MFC), fuelled with domestic wastewater in the anodic chamber, to degrade a simulated textile dye effluent made of Remazol Brilliant Blue R inoculated with an immobilised fungal strain, Pleurotus ostreatus URM 4809, as a laccase producer, in the cathodic chamber. The MFC showed continuous synthesis of laccase in the cathodic chamber, which, in turn, promoted the rapid decolourisation, of more than $86 \%$ of the textile dye effluent. The yield was further increased by the addition of glycerol. Electrochemical monitoring also indicated an increase in power density and current density. After 20 days of MFC operation, $62.1 \%$ of organic matter was removed in the anodic compartment, thus leaving the effluent with a much lower toxicity.
\end{abstract}

Keywords Microbial fuel cell · Pleurotus ostreatus $\cdot$ Laccase $\cdot$ Remazol Brilliant Blue R · Vigna radiata

\section{Introduction}

Synthetic dyes have been extensively applied in many different industries, such as cosmetics, food, plastics, textiles, and pharmaceuticals (Salazar-López et al. 2017). Varghese et al. (2018) estimated that an annual volume of 160-240 thousands of tons of wastewater is discarded from dyes

Electronic supplementary material The online version of this article (https://doi.org/10.1007/s10311-019-00876-y) contains supplementary material, which is available to authorized users.

Cristiane Angélica Ottoni

cristiane.ottoni@unesp.br

1 Biology Department, Edge Hill University, St Helens Road, Lancashire, Ormskirk L39 4QP, UK

2 Laboratório de Biotecnologia Industrial, Instituto de Pesquisas Tecnológicas do Estado de São Paulo, São Paulo, SP 05508-901, Brazil

3 Centre of Biological Engineering, University of Minho, Campus of Gualtar, 4710-057 Braga, Portugal

4 Centro de Célula a Combustível e Hidrogênio, Instituto de Pesquisas Energéticas e Nucleares, São Paulo, SP 05508-000, Brazil production. These numbers show that dyes are a major cause of water pollution. These compounds are often classified by their chromophore group as azo, anthraquinone, triphenylmethane, heterocyclic or phthalocyanine dyes ( $\mathrm{Lu}$ et al. 2016). After azo dyes, anthraquinones are the second most important class of dyes (Afreen et al. 2017). Furthermore, it is well known that the presence of dyes in water, mainly azo and anthraquinones, causes high risks for human health and environmental ecosystems since these can be toxic, carcinogenic, mutagenic or allergenic (Tarkwa et al. 2018).

5 Department of Biosystems Sciences and Engineering, Institute of Agronomy, University of Lisbon, Tapada da Ajuda, Lisbon 1349-017, Portugal

6 São Paulo State University (UNESP), São Vicente, SP 11380-972, Brazil

7 Instituto de Estudos Avançados do Mar (IEAMar/UNESP), São Vicente, SP, Brazil

8 Bioscience Institute, São Paulo State University, São Vicente 11330-900, Brazil 
Over the last two decades, many efforts have been made in order to replace conventional large-scale dye treatments with biological systems. In this context, bioremediation is considered an interesting approach for being a low-cost process and environmental friendly. Due to their physiological and morphological characteristics, filamentous fungi, mainly white rot fungus, have become the main microbial group applied to degrade this complex class of pollutant (Wang et al. 2017). Several studies have been done regarding the application of white rot fungus to decolourise and degrade Remazol Brilliant Blue R, an important anthraquinone dye used in the textile industry (Patel et al. 2017; Orlikowska et al. 2018; Vats and Mishra 2018). However, until now, none of these studies applied Remazol Brilliant Blue R decolourisation/degradation integrating white rot fungus and MFC approach.

Presently, the main objectives of wastewater treatment are to simultaneously remove contaminants and to recover both energy and useful resources in a more efficient and eco-friendly way (Rezakazemi et al. 2018a, b; Saeed et al. 2018; Hajilary et al. 2018). For the removal of contaminants, such as dyes, nanosized adsorbents, nanocomposite membranes and photodegradation techniques have been used (Shukla and Oturan 2015; Kolangare et al. 2018; Mudhoo et al. 2018). Several studies have been considering microbial fuel cells (MFCs) technology as a promising approach for the removal of pollutants coupled with the generation of electricity (Ilamathi and Jayapriya 2018; Ottoni et al. 2019; Wang et al. 2018). According to Ilamathi and Jayapriya (2018), around 50-90\% less solids will be disposed using this system.

Typically, MFCs use electrochemically active bacteria that promote organic matter oxidation and convert it into electricity (Peixoto et al. 2013; Izadi and Rahimnejad 2014; Jadhav et al. 2014). In recent years, this technique was applied in synthetic, domestic and industrial wastewaters (Liu et al. 2011). The most common MFC architecture is composed of an anodic and a cathodic chamber separated by an ion-conducting membrane. In the anode chamber, microbes oxidise the substrates that generate electrons and protons, and subsequently, electrons are transferred to the cathode through an external circuit and protons through the internal membrane. Electrons and protons are consumed in the cathode, reducing oxygen or an alternative electron acceptor ( $\mathrm{Lu}$ et al. 2009). The power output of wastewater in MFC is dependent from numerous parameters, including activity and concentration of electrochemical microorganisms, electrodes, type of proton exchange membrane, reactor design, organic load value and external resistance (Sharma and Kundu 2010; Campo et al. 2013; Sonawane et al. 2014). However, one of the most important parts involved in the MFCs performance, that several researchers have been dedicating the efforts to improve, is the cathode chamber. Its poor kinetics of oxygen reduction reaction are the main reason for increased focus on its studies. The most desired factor in the development of new cathodes for MFCs is the use of inexpensive materials that lack precious metals (Zhang et al. 2011; Watson et al. 2013). When it comes to the cathodic electrode surface, the goal is to have a cathode catalyst that has a high performance, decreases the activation energy barrier, improves the reactive kinetics, and at the same time is cost-effective. Enzymes used as cathode catalysts can potentially eliminate limiting factors in biocathodes, such as decreasing efficiency due to accumulation of metabolites, carbon source requirements, and specificity in catalysing electron transfer (Luo et al. 2010).

Recently, a new biocathode was developed using microorganisms and their enzymes as catalysts to assist in electron transfer, eliminate the use of noble metal (such as platinum), and eliminate the need for replenishment of the electron mediator, resulting in greatly improved MFC and enzymatic fuel cell sustainability (Franks and Nevin 2010; Sun et al. 2011; Hou et al. 2014). Biological catalysts may offer a solution to circumvent the limiting factors of MFC, by catalysing cathodic oxygen reduction reactions at high onset potentials under conditions compatible with microbial activity (Strack et al. 2013). In this regard, some studies developed by Chaijak et al. (2018) and Sané et al. (2013) described the application of fungi that synthetise laccase as a biocathode. Beyond this application, laccase has also been extensively applied in different sectors such as paper pulping and bleaching, textile refining, dye decolorisation, bioremediation, organic synthesis, and juice and wine clarification (Yang et al. 2014). Furthermore, laccase has low substrate specificity, utilises oxygen as final electron acceptor, and produces water as its only by-product (Wu et al. 2012).

Morant et al. (2014) cultivated the fungal strains Aspergillus sp. SIS-18, Penicillium sp. SIS-21, and Rhizopus sp. SIS-31 in an air-cathode MFC. Significant changes in current densities were observed from the $72 \mathrm{~h}$ up to the end of the experiment, at $120 \mathrm{~h}$. Maximum current densities were observed for SIS-31, followed by SIS-21, and SIS-18, with $125.75,98.68$, and $29.75 \mathrm{~mA} \mathrm{~cm}^{-2}$, respectively, while for the experiment containing pure laccase from the white rot fungi Trametes versicolor, the lowest current density of $11.47 \mathrm{~mA} \mathrm{~cm}^{-2}$ was observed. The authors concluded that the oxygen reduction in the air biocathodes can be efficiently performed and enhanced by the use of in situ fungal cultures. Sané et al. (2013) also used T. versicolor, but they used a crude culture supernatant to supply the unpurified enzyme laccase to a biofuel cell cathode. This operational strategy decreases time and costs usually spent on enzymes' purification. In addition, it was shown that by regular exchange of the crude culture supernatant it is possible to extend the lifetime of the cathode by at least five times. 
Oon et al. (2018a) evaluated MFC performance to degrade new coccine dye and produce bioelectricity. The maximum power density that they obtained was $20.13 \pm 0.37 \mathrm{~mW} /$ $\mathrm{m}^{-3}$ with the addition of $25 \mathrm{mg} / \mathrm{L}$ new coccine, which was $17 \%$ higher than the dye-free condition. In another study, Oon et al. (2018b) described decolourisation efficiency at $500 \mathrm{mg} / \mathrm{L}$ of Acid Red 18 using an up-flow constructed wetland MFC system. Savizi et al. (2012) studied the enzymatic decolourisation of the azo dye Reactive Blue 221, catalysed by immobilised laccase, in the cathode chamber of a MFC. They observed that the enhancement of MFC performance under decolourisation condition could be attributed to the phenomena occurring simultaneously: oxygen reduction by laccase and reduction of the product of Reactive Blue 221 decolourisation. Laccase in the cathode chamber was able to catalyse the oxygen reduction reaction through electron capture from the cathode surface. The product of Reactive Blue 221 oxidation had a redox potential which was thermodynamically preferable to be reduced by receiving electrons from the cathode. Therefore, the main focus of this research was to improve domestic wastewater treatment paired with bioelectricity generation in a MFC.

\section{Materials and methods}

\section{Selected fungal strain}

Pleurotus ostreatus URM 4809 was obtained from the Micoteca URM culture collection (URM, Recife, Brazil). The strain was grown on malt extract agar (MEA: $20 \mathrm{~g} \mathrm{~L}^{-1}$ malt, $20 \mathrm{~g} \mathrm{~L}^{-1}$ glucose, $1 \mathrm{~g} \mathrm{~L}^{-1}$ peptone, $20 \mathrm{~g} \mathrm{~L}^{-1}$ agar, in distilled water), and a spore suspension was prepared and preserved in $20 \%$ glycerol, at $-80{ }^{\circ} \mathrm{C}$, for future use.

\section{Microbial fuel cell inoculum}

The inoculum in the cathodic chamber was initially prepared in a 250 -mL Erlenmeyer flask containing $50 \mathrm{~mL}$ of simulated textile dye effluent $\left(5 \mathrm{~g} \mathrm{~L}^{-1}\right.$ glucose, $0.5 \mathrm{~g} \mathrm{~L}^{-1}$ yeast extract, $0.5 \mathrm{~g} \mathrm{~L}^{-1} \mathrm{NaNO}_{3}, 0.2 \mathrm{~g} \mathrm{~L}^{-1} \mathrm{KH}_{2} \mathrm{PO}_{4}, 0.05 \mathrm{~g} \mathrm{~L}^{-1}$ $\mathrm{MgSO}_{4} \cdot 7 \mathrm{H}_{2} \mathrm{O}, 0.03 \mathrm{~g} \mathrm{~L}^{-1} \mathrm{MnCl} 2 \cdot 4 \mathrm{H}_{2} \mathrm{O}, 0.002 \mathrm{~g} \mathrm{~L}^{-1} \mathrm{CuSO}_{4}$. $5 \mathrm{H}_{2} \mathrm{O}, 0.001 \mathrm{~g} \mathrm{~L}^{-1} \mathrm{FeSO}_{4} \cdot 7 \mathrm{H}_{2} \mathrm{O}$ and $0.05 \mathrm{~g} \mathrm{~L}^{-1}$ Remazol Brilliant Blue R).

The simulated textile dye effluent in the Erlenmeyer flask was inoculated with $0.5 \mathrm{~mL}$ of a spore suspension from the selected fungal strain, containing around $10^{7}$ spores $\mathrm{mL}^{-1}$, and incubated in a rotary shaker (Marconi, Brazil), at $30{ }^{\circ} \mathrm{C}$ and $150 \mathrm{rpm}$, for 7 days. Two nylon sponge cubes, $1 \mathrm{~cm}^{3}$, were used as fungal support, and the pre-treatment of nylon sponge was performed according to the method described elsewhere (Rodríguez-Couto et al. 2004). After this time, the nylon sponge supports were transferred to a sterile filtration apparatus and washed thoroughly, with $150 \mathrm{~mL}$ of sterile distilled water, to remove the free biomass. The anodic chamber inoculum was collected at a domestic wastewater treatment plant (São Paulo, Brazil) and treated as previously described by Peixoto et al. (2013).

\section{Microbial fuel cell description and operation}

The dual-chamber MFC, made of transparent poly methyl methacrylate, consisted of two compartments with equal dimensions $(12 \mathrm{~cm} \times 8 \mathrm{~cm} \times 5 \mathrm{~cm})$, physically separated by a proton exchange membrane (Nafion Membrane 117, DuPont Co., USA), sealed with a silicone rubber. In order to assemble the two chambers and to keep it tight, rubber gaskets and stainless-steel screws were used. The net working volume used for each chamber was $320 \mathrm{~mL}$. The electrodes, both carbon Toray TP-090 (QUINTECH, USA) sheets (each, $4 \mathrm{~cm} \times 4 \mathrm{~cm}=16 \mathrm{~cm}^{2}$ ), were connected to an external resistance using copper-coated wires ( $2 \mathrm{~mm}$ diameter). Domestic wastewater (with an average chemical oxygen demand (COD) concentration of $464 \pm 20 \mathrm{mg} \mathrm{L}^{-1}$ ) was used as a batch stirred anolyte at room temperature $\left(30^{\circ} \mathrm{C}\right)$.

The immobilised fungal strain was fixed into the cathode chamber, and the compartment was filled with simulated textile dye effluent. During the experiments, the additional carbon source (glycerol, with a final concentration of $10 \mathrm{mM}$ ) was supplied, maintaining the metabolic condition of the white rot fungus. The chamber was continuously aerated using a filtered air pump system (SEAFLO, China).

In order to analyse the advantages of using the immobilised fungus to synthetise laccase and enhance the oxygen reduction reaction in the cathode chamber, another MFC was operated, for comparison purposes, with the same conditions but without fungus in the cathode chamber.

Power density, dye decolourisation and enzymatic activity were monitored daily, while COD and phytotoxicity were analysed at the beginning and end of the experiment. All of these are described in the following sections.

\section{Analyses}

MFC power output was monitored by measuring the voltage across a fixed $1 \mathrm{k} \Omega$ resistance, using a digital multimeter (Fluke $87 \mathrm{~V}$, EUA), every $24 \mathrm{~h}$. The current $(I)$ generation and power $(P)$ output were calculated by Ohm's law, using the relations $I=E / R$ and $P=I E$, where $I$ is the current, $E$ the voltage, $R$ the external resistance, and $P$ the power. Power density and current density were based on the surface anode area (Wang et al. 2017).

Concentrations of Remazol Brilliant Blue $\mathrm{R}$ dye were determined by UV-visible spectrophotometry technique, with a decrease in absorption intensity at the maximum wavelength $596 \mathrm{~nm}$, in a spectrophotometer Hach (DR6000 
UV/VIS, Brazil). COD was determined by Fogelman et al. (2006) method.

\section{Laccase activity assay}

The laccase activity $\left(\varepsilon_{525 \mathrm{~mm}}=65,000 \mathrm{M}^{-1} \mathrm{~cm}^{-1}\right)$ was determined by syringaldazine oxidation by the increase in absorbance at $525 \mathrm{~nm}$ (Martins et al. 2003). For each enzymatic activity assay, the same reaction mixtures, containing boiled supernatant samples, were employed as a blank. One unit (U) of enzyme activity was defined as the amount of the enzyme responsible for the change of 0.01 of absorbance per minute under the assay conditions. Enzyme activity of all the samples was expressed as units per litre $\left(\mathrm{U} \mathrm{L}^{-1}\right)$.

\section{Phytotoxicity assay}

Phytotoxicity methods were adapted from protocols described by Hashmat et al. (2014) and Nouren and Bhatti (2015). Briefly, seeds of beans (Vigna radiata) were exposed to samples of the dye treatment collected at different times. Seeds germination was measured after 5 days of incubation (16-h light plus 8-h dark, per day), at room temperature $\left(25^{\circ} \mathrm{C}\right)$. Four replicates of 10 seeds were used for each test. Distilled water and Remazol Brilliant Blue R solution (100 $\mathrm{mg} \mathrm{L}^{-1}$ ) were used as controls. Growth of Vigna radiata watered with fungal decolourised water was compared with the growth of Vigna radiata watered with distilled water and Remazol Brilliant Blue R solution $\left(100 \mathrm{mg} \mathrm{L}^{-1}\right)$. The germination index (GI) was determined using an expression previously defined (Hashmat et al. 2014): GI $=\% G \cdot L_{\mathrm{a}} / L_{\mathrm{c}}$, where $\% \mathrm{G}$ is the number of germinated seeds expressed as $\%$ of control values, $L_{\mathrm{a}}$ is the average value of root length when exposed to treatments, and $L_{\mathrm{c}}$ is the average value of root length in the control.

\section{Results and discussion}

\section{Dye decolourisation and laccase activities in the cathode chamber}

With the purpose of applying fungal laccase to improve MFC performance, a set of experiments was performed using immobilised $P$. ostreatus URM 4809 cells in a MFC cathodic chamber, for continuous laccase synthesis and anthraquinone Remazol Brilliant Blue $\mathrm{R}$ dye decolourisation. This strain was chosen for being reported as a laccase producer (Hou et al. 2004; Téllez-Téllez et al. 2008). Regarding the choice of support, it has been previously demonstrated that nylon sponge can be a very good matrix, among others (Bouabidi et al. 2018), like polyurethane foam (Sultan 2017), both being firm and inert choices to immobilise biomass used in studies for decolourisation of Remazol Brilliant Blue $\mathrm{R}$ and for the treatment of textile wastewaters.

With the selected strain and MFC setting for this research, it was possible to show that Remazol Brilliant Blue R decolourisation ranged from 80 to $90 \%$ in four continuous cycles (Fig. 1a, b). Furthermore, the higher laccase activity of 929.6 $\mathrm{U} \mathrm{L}^{-1}$ was detected on the 10th day of MFC operation, after the glycerol pulse. This profile of laccase synthesis is in accordance with the previous work developed by Ottoni et al. (2014), who described the use of glycerol as an additional carbon source on dye decolourisation process, to be a good inducer of enzyme synthesis.

Lai et al. (2017a) used a strain of Ganoderma lucidum, also a white rot fungus, on the cathode surface of a singlechamber MFC, in order to continuously produce laccase and consequently increase Acid Orange 7 dye decolourisation and electricity production. According to these authors, laccase reached a maximum activity of $20.3 \pm 0.3 \mathrm{U} \mathrm{L}^{-1}$ and promoted $>90 \%$ of the dye decolourisation $\left(50 \mathrm{mg} \mathrm{L}^{-1}\right)$. In a



(a) Dye decolourisation (\%)

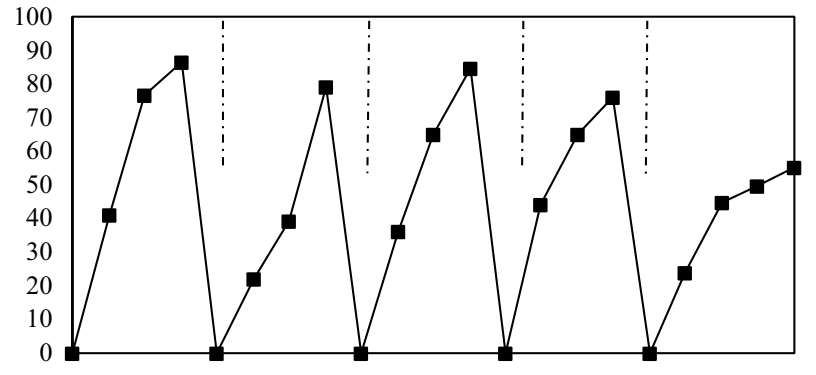

(b) Laccase $\left(\mathbf{U} \cdot \mathbf{L}^{-1}\right)$

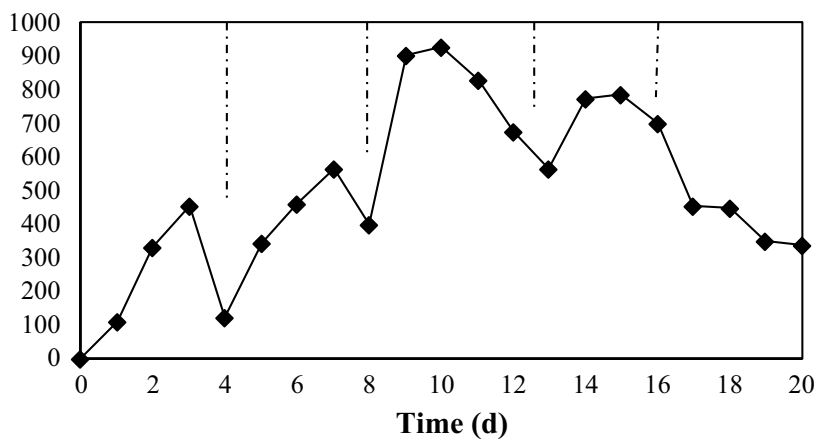

Fig. 1 a Profile of Remazol Brilliant Blue R (\%) decolourisation (black square) and $\mathbf{b}$ Laccase activity $\left(\mathrm{U} \mathrm{L}^{-1}\right)$ (black diamond), in a microbial fuel cell operated for 20 days 
different study conducted by Lai et al. (2017b), Ganoderma lucidum BCRC 36123 was used as a fungus biocathode for azo dye Acid Orange 7 decolourisation and simultaneous electrical generation in an air-cathode MFC. The air-cathode MFC presented $96.7 \%$ decolorisation of $500 \mathrm{mg} \mathrm{L}^{-1}$ Acid Orange 7. According to the authors, the auxiliary action of the laccase was fundamental to excel the performance of this system.

Mani et al. (2017) used commercial laccase from Trametes versicolor $\left(13.6 \mathrm{U} \mathrm{mg}^{-1}\right)$ in the cathode chamber and AO7 dye in anode chamber and obtained the best MFC operation at $89 \%$ of dye decolourisation. In contrast, Oon et al. (2017) employed New coccine, Acid Orange 7, Reactive red 120 and Reactive green 19 dyes, as electron acceptors in the abiotic cathode, obtaining the most efficient dye decolorisation with $\mathrm{NC}, 95.1 \pm 1.1 \%$, followed by Acid Orange $7,94.9 \pm 0.9 \%$. However, the power density obtained was lower than in all the studies referred above conducted with MFC laccase in the cathode chamber. In fact, Bakhshian et al. (2011) described laccase as having dual function in the MFC cathode, acting as a catalyst for oxygen reduction reaction and catalyse dye decolourisation.

The MFC system using a fungus-bacterium (Trametes versicolor-Shewanella oneidensis) combination is a costeffective alternative to the common MFCs used to generate electricity and treat organic wastewater and is developed by Fernández de Dios et al. (2013). This system allows stable electricity generation, enhanced by the electro-Fenton reactions that occur in the cathode chamber. Just like the model proposed in this manuscript, Fernández de Dios et al.'s (2013) configuration also has dual benefits: simultaneous dye decolourisation and the electricity generation, which are demonstrated through a stable voltage of approximately $1000 \mathrm{mV}$ and a maximum volumetric power density of $0.78 \mathrm{Wm}^{3}$ per liquid volume in the anode.

\section{Chemical oxygen demand removal and co-generation electricity}

After 20 days in the MCF laccase operated at a fixed external resistance of $1000 \Omega$, COD removal was approximately $62.1 \%$, and maximum power density generated was $180.5 \mathrm{~mW} \mathrm{~m}^{-2}$ (Fig. 2a, b) and current density detected was $12.4 \mathrm{~mA} \mathrm{~m}^{-2}$. The power density increased in the same period that laccase presented higher activity level, and after that, it began to decrease gradually. These results were 9.69 times higher when compared to the control (Figs. 1a, b, 2a, b, Supplementary material).

Lin et al. (2018) added laccase from Ganoderma lucidum to the broth in the cathode chamber, favouring the redox reaction, and obtained $84 \%$ of COD removal in the anode chamber and a power density of $40 \mathrm{~mW} \mathrm{~cm} \mathrm{~cm}^{2}$, maintaining electricity energy for 45 days. Kacem et al. (2017)

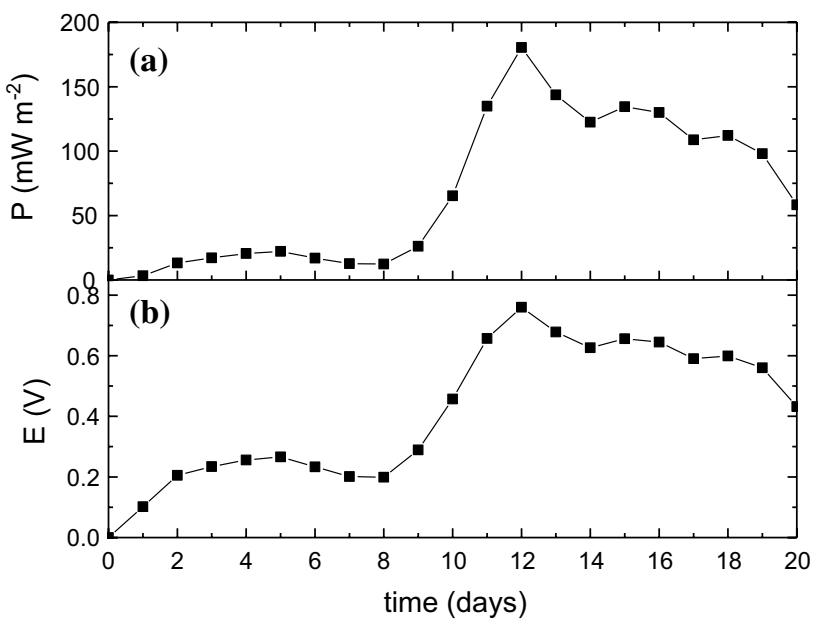

Fig. 2 a Potential $(\mathrm{P})$ and $\mathbf{b}$ power density $(E)$ of the microbial fuel cell operated for 20 days

Table 1 Phytotoxicity of the Remazol Brilliant Blue R for seeds of Vigna radiata

\begin{tabular}{llll}
\hline & Distilled water & Untreated dye & Treated dye \\
\hline Germination index (\%) & 100 & 45 & 78 \\
Root length (cm) & $4.27 \pm 0.322$ & $2.16 \pm 0.432$ & $3.22 \pm 0.675$ \\
Shoot length $(\mathrm{cm})$ & $3.34 \pm 0.228$ & $1.13 \pm 0.452$ & $2.87 \pm 0.398$ \\
\hline
\end{tabular}

immobilised commercial laccase in polymer inclusion ionic liquid membranes and applied it in single-chamber air-cathode MFC obtaining a COD removal rate of $70 \%$, in fresh wastewater collected from a mineral oil manufacturing company. Similarly to these studies, other authors (Schaetzle et al. 2009; Sané et al. 2014) also consider laccase as a relevant component that improves the performance of MFCs, and this approach as a promising sustainable technology is not only for bioenergy production but also for wastewater treatment.

\section{Phytotoxicity}

The seeds of Vigna radiata were used to study the effect of the different solutions on germination. The seeds exposed to Remazol Brilliant Blue R dye, before and after treatment, in MFC presented a dose-dependent inhibitory effect on germination, as well as on growth, and development (Table 1). The seeds exposed to the dye without the treatment showed a germination rate of 55\% lower when compared to the control. Contrary to this, those exposed to the residue of the Remazol Brilliant Blue $\mathrm{R}$ dye, obtained after 20 days of treatment in the cathode compartment of the MFC, only showed a germination index $22 \%$ lower than the control. These data 
corroborate previous studies, for various dyes, conducted with this type of seed.

According to Karthikeyan et al. (2017), the germination index and growth of Vigna radiata seeds, treated with the products of the biodegradation of the Remazol Brilliant Blue R dye by Staphylococcus sp. K2204, were higher when compared to the seeds exposed to the Remazol Brilliant Blue R (100 $\mathrm{mg} \mathrm{L}^{-1}$ ). Furthermore, Aravind et al. (2016) observed that the increase in mono-azo dyes Reactive Red 195 and Reactive Orange 105 concentrations visibly affects the growth of Vigna radiata. All of these justify the choice of Vigna radiate for the analysis of Remazol Brilliant Blue $\mathrm{R}$ toxicity.

Moreover, the reduction of Remazol Brilliant Blue R toxicity in MFC is intrinsically associated with the presence of laccase. However, this is the first report of the highly efficient rate of decolourisation and toxicity of an anthraquinone in an MFC, since in most studies azo dyes are used.

\section{Conclusion}

Continuous laccase synthesis by Pleurotus ostreatus URM 4809 in the MFC cathodic chamber promoted both anthraquinone dye decolourisation (up to 86\%) and higher power density $\left(180.5 \mathrm{~mW} \mathrm{~m}^{-2}\right)$ when compared with other studies that applied similar concepts. Phytotoxicity results indicate that the decolourisation process did not generate detectable toxic products. Our system should be scaled up and can be considered an eco-friendly treatment. Nevertheless, additional work will need to be done to better understand how electricity generation affects COD removal and how operational factors such as hydraulic retention time and air flow rate through the cathode can be optimised.

Acknowledgements Authors would like to acknowledge the technician and financial support of Programa Novos Talentos provided by the Instituto de Pesquisa Tecnológica do Estado de São Paulo (IPT) and Instituto de Estudos Avançados do Mar (IEAMar).

\section{Compliance with ethical standards}

Conflicts of interest There are no conflicts to declare.

\section{References}

Afreen S, Bano F, Ahmad N, Fatma T (2017) Screening and optimization of laccase from cyanobacteria with its potential in decolorization of anthraquinonic dye Remazol Brilliant Blue R. Biocatal Agric Biotechnol 10:403-410. https://doi.org/10.1016/j. bcab.2017.05.004

Aravind P, Selvaraj H, Ferro S, Sundaram M (2016) An integrated (electro-and bio-oxidation) approach for remediation of industrial wastewater containing azo-dyes: understanding the degradation mechanism and toxicity assessment. J Hazard Mater 318:203-215. https://doi.org/10.1016/j.jhazmat.2016.07.028

Bakhshian S, Kariminia H-R, Roshandel R (2011) Bioelectricity generation enhancement in a dual chamber microbial fuel cell under cathodic enzyme catalyzed dye decolorization. Bioresour Technol 102:6761-6765. https://doi.org/10.1016/j.biortech.2011.03.060

Bouabidi ZB, El-Naas MH, Zhang Z (2018) Immobilization of microbial cells for the biotreatment of wastewater: a review. Environ Chem Lett. https://doi.org/10.1007/s10311-018-0795-7

Campo AG, Cañizares P, Rodrigo MA, Fernández FJ, Lobato J (2013) Microbial fuel cell with an algae-assisted cathode: a preliminary assessment. J Power Sources 242:638-645. https://doi. org/10.1016/j.jpowsour.2013.05.110

Chaijak P, Sukkasem C, Lertworapreecha M, Boonsawang P, Wijasika S, Sato C (2018) Enhancing electricity generation using a laccase-based microbial fuel cell with yeast Galactomyces reessii on the cathode. J Microbiol Biotechnol 28:1360-1366. https:// doi.org/10.4014/jmb.1803.03015

Fernández de Dios MÁ, del Campo AG, Fernández FJ, Rodrigo M, Pazos M, Sanromán MÁ (2013) Bacterial-fungal interactions enhance power generation in microbial fuel cells and drive dye decolorisation by an ex situ and in situ electro Fenton process. Bioresour Technol 148:39-46. https://doi.org/10.1016/j.biort ech.2013.08.084

Fogelman S, Zhao H, Blumenstein M (2006) A rapid analytical method for predicting the oxygen demand of wastewater. Anal Bioanal Chem 386:1773-1779. https://doi.org/10.1007/s0021 6-006-0817-3

Franks AE, Nevin KP (2010) Microbial fuel cells, a current review. Energies 3:899-919. https://doi.org/10.3390/en3050899

Hajilary N, Rezakazemi M, Shirazian S (2018) Biofuel types and membrane separation. Environ Chem Lett. https://doi.org/10.1007/ s10311-018-0777-9

Hashmat AJ, Islam E, Haq MA, Khan QM (2014) Integrated treatment technology for textile effluent and its phytotoxic evaluation. Desalin Water Treat 57:4146-4156. https://doi.org/10.1080/19443 994.2014.989270

Hou H, Zhou J, Wang J, Du C, Yan B (2004) Enhancement of laccase production by Pleurotus ostreatus and its use for the decolorization of anthraquinone dye. Process Biochem 39(11):1415-1419. https://doi.org/10.1016/S0032-9592(03)00267-X

Hou J, Dong G, Ye Y, Chen V (2014) Laccase immobilization on titania nanoparticles and titania-functionalized membranes. J Membr Sci 452:229-240. https://doi.org/10.1016/j.memsci.2013.10.019

Ilamathi R, Jayapriya J (2018) Microbial fuel cells for dye decolorization. Environ Chem Lett 16:239-250. https://doi.org/10.1007/ s1031

Izadi P, Rahimnejad M (2014) Simultaneous electricity generation and sulfide removal via a dual chamber microbial fuel cell. Biofuel Res J 1:34-38. https://doi.org/10.18331/brj2015.1.1.8

Jadhav DA, Ghadge AN, Ghangrekar MM (2014) Simultaneous organic matter removal and disinfection of wastewater with enhanced power generation in microbial fuel cell. Bioresour Technol 163:328-334. https://doi.org/10.1016/j.biortech.2014.04.055

Kacem SH, Galai S, Ríos AP, Fernández FJH, Smaali I (2017) New efficient laccase immobilization strategy using ionic liquids for biocatalysis and microbial fuel cells applications. J Chem Technol Biotechnol 93:174-183. https://doi.org/10.1002/jctb.5337

Karthikeyan V, Kumar MA, Mohanapriya P, Amudha T, Thiruselvi D, Karthik P, Sivanesan S (2017) Biodegradation of Remazol Brilliant Blue R using isolated bacterial culture (Staphylococcus sp. K2204). Environ Technol 39:2900-2907. https://doi. org/10.1080/09593330.2017.1369579

Kolangare IM, Isloor AM, Karim ZA, Kulal A, Ismail AF, Inamuddin Asiri AM (2018) Antibiofouling hollow-fiber membranes for dye rejection by embedding chitosan and silver-loaded chitosan 
nanoparticles. Environ Chem Lett. https://doi.org/10.1007/s1031 1-018-0799-3

Lai C-Y, Wu G-P, Meng C-T, Lin C-W (2017a) Decolorization of azo dye and generation of electricity by microbial fuel cell with laccase-producing white-rot fungus on cathode. Appl Energy 188:392-398. https://doi.org/10.1016/j.apenergy.2016.12.044

Lai C-Y, Liu S-H, Wu G-P, Lin C-W (2017b) Enhanced bio-decolorization of acid orange 7 and electricity generation in microbial fuel cells with superabsorbent-containing membrane and laccase-based bio-cathode. J Clean Prod 166:381-386. https:// doi.org/10.1016/j.jclepro.2017.08.047

Lin CW, Wu C-H, LinY-Y Liu S-H, Chang S-H (2018) Enhancing the performance of microbial fuel cell using a carbon-fiber-brush air cathode with low-cost mushroom Ganoderma laccase enzyme. J Taiwan Inst Chem E. https://doi.org/10.1016/j.jtice.2017.12.025

Liu G, Yates MD, Cheng S, Call DF, Sun D, Logan BE (2011) Examination of microbial fuel cell start-up times with domestic wastewater and additional amendments. Bioresour Technol 102:73017306. https://doi.org/10.1016/j.biortech.2011.04.087

Lu N, S-g Zhou, Zhuang L, Zhang J-T, Ni J-R (2009) Electricity generation from starch processing wastewater using microbial fuel cell technology. Biochem Eng J 43:246-251. https://doi.org/10.1016/j. bej.2008.10.005

Lu R, Ma L, He F, Yu D, Fan R, Zhang Y, Long Z, Zhang X, Yang Y (2016) White-rot fungus Ganoderma sp. En3 had a strong ability to decolorize and tolerate the anthraquinone, indigo and triphenylmethane dye with high concentrations. Bioprocess Biosyst Eng 39:381-390. https://doi.org/10.1007/s00449-015-1521-5

Luo H, Jin S, Fallgren PH, Park HJ, Johnson PA (2010) A novel laccase-catalyzed cathode for microbial fuel cells. Chem Eng J 165:524-528. https://doi.org/10.1016/j.cej.2010.09.061

Mani P, Keshavarz T, Chandra TS, Kyazze G (2017) Decolourisation of Acid orange 7 in a microbial fuel cell with a laccase-based biocathode: influence of mitigating $\mathrm{pH}$ changes in the cathode chamber. Enzyme Microb Technol 96:170-176. https://doi. org/10.1016/j.enzmictec.2016.10.012

Martins MAM, Lima N, Silvestre AJD, Queiroz MJ (2003) Comparative studies of fungal degradation of single or mixed bioaccessible reactive azo dyes. Chemosphere 52:967-973. https://doi. org/10.1016/S0045-6535(03)00286-8

Morant KV, Silva PH, Campos-Takaki GM, Hernández CER (2014) Isolation and bioelectrochemical characterization of novel fungal sources with oxidasic activity applied in situ for the cathodic oxygen reduction in microbial fuel cells. Enzyme Microb Technol 66:20-27. https://doi.org/10.1016/j.enzmictec.2014.07.007

Mudhoo A, Gautam RK, Ncibi MC, Zhao F, Garg VK, Sillanpää M (2018) Green synthesis, activation and functionalization of adsorbents for dye sequestration. Environ Chem Lett. https://doi. org/10.1007/s1031

Nouren S, Bhatti HN (2015) Mechanistic study of degradation of basic violet 3 by citrus limon peroxidase and phytotoxicity assessment of its degradation products. Biochem Eng J 95:9-19. https://doi. org/10.1016/j.bej.2014.11.021

Oon Y-S, Ong S-A, Ho L-N, Wong Y-S, Oon Y-L, Lehl HK, Thung W-E, Nordin N (2017) Microbial fuel cell operation using monoazo and diazo dyes asterminal electron acceptor for simultaneous decolourisation and bioelectricity generation. J Hazard Mater 325:170-177. https://doi.org/10.1016/j.jhazmat.2016.11.074

Oon Y-S, Ong SA, Ho L-N, Wong Y-S, Oon Y-L, Lehl HK, Thung W-E, Nordin N (2018a) Disclosing the synergistic mechanisms of azo dye degradation and bioelectricity generation in a microbial fuel cell. Chem Eng J 344:236-245. https://doi.org/10.1016/j. cej.2018.03.060

Oon Y-L, Ong S-A, Ho L-N, Wong Y-S, Dahalan FA, Oon Y-S, Lehl HK, Thung W-E, Nordin N (2018b) Up-flow constructed wetland-microbial fuel cell for azo dye, saline and nitrate remediation and bioelectricity generation: from waste to energy approach. Bioresour Technol 266:97-108. https://doi. org/10.1016/j.biortech.2018.06.035

Orlikowska M, Rostro-Alanis MJ, Bujacz A, Hernández-Luna C, Rubio R, Parra R, Bujacz G (2018) Structural studies of two thermostable laccases from the white-rot fungus Pycnoporus sanguineus. Int J Biol Macromol 107:1629-1640. https://doi. org/10.1016/j.ijbiomac.2017.10.024

Ottoni C, Lima L, Santos C, Lima N (2014) Effect of different carbon sources on decolourisation of an industrial textile dye under alkaline-saline conditions. Curr Microbiol 68:53-58. https:// doi.org/10.1007/s00284-013-0441-3

Ottoni CA, Simões MF, Santos JG, Peixoto L, Martins CR, Silva BP, Neto AO, Brito AG, Maiorano AE (2019) Application of microbial fuel cell technology for vinasse treatment and bioelectricity generation. Biotechnol Lett 41:107-114. https://doi. org/10.1007/s10529-018-2624-2

Patel AM, Patel VM, Pandya J, Trivedi UB, Patel KC (2017) Evaluation of catalytic efficiency of Coriolopsis caperata DN laccase to decolorize and detoxify RBBR dye. Water Conserv Sci Eng 2:85-98. https://doi.org/10.1007/s4110

Peixoto L, Rodrigues AL, Martins G, Nicolau A, Brito AG, Silva MM, Parpot P, Nogueira R (2013) A flat microbial fuel cell for decentralized wastewater valorization: process performance and optimization potential. Environ Technol 34:1947-1956. https:// doi.org/10.1080/09593330.2013.827223

Rezakazemi M, Khajeh A, Mesbah M (2018a) Membrane filtration of wastewater from gas and oil production. Environ Chem Lett 16:367-388. https://doi.org/10.1007/s10311-017-0693-4

Rezakazemi M, Dashti A, Harami HR, Hajilari N, Inamuddin (2018b) Fouling-resistant membranes for water reuse. Environ Chem Lett 16:715-763. https://doi.org/10.1007/s1031 1-018-0717-8

Rodríguez-Couto S, Sanromán MA, Hofer D, Gübitz GM (2004) Stainless steel sponge: a novel carrier for the immobilization of the white-rot fungus Trametes hirsuta for decolourization of textile dyes. Bioresour Technol 95:67-72. https://doi. org/10.1016/j.biortech.2003.05.002

Saeed M, Ahmad A, Boddula R, Inamuddin, ul Haq A, Azhar A (2018) Ag@MnxOy: an effective catalyst for photo-degradation of rhodamine B dye. Environ Chem Lett 16:287-294. https:// doi.org/10.1007/s10311-017-0661-z

Salazar-López M, Rostro-Alanis MJ, Castillo-Zacarías C, ParraGuardado AL, Hernández-Luna C, Iqbal HMN, Parra-Saldivar R (2017) Induced degradation of anthraquinone-based dye by laccase produced from Pycnoporus sanguineus (CS43). Water Air Soil Pollut 228:469. https://doi.org/10.1007/s1127 0-017-3644-6

Sané S, Jolivalt C, Mittler G, Nielsen PJ, Rubenwolf S, Zengerle R, Kerzenmacher S (2013) Overcoming bottlenecks of enzymatic biofuel cell cathodes: crude fungal culture supernatant can help to extend lifetime and reduce cost. Chemsuschem 6:1209-1215. https://doi.org/10.1002/cssc.20130020

Sané S, Richter K, Rubenwolf S, Matschke NJ, Jolivalt C, Madzak C, Zengerle R, Gescher J, Kerzenmacher S (2014) Using planktonic microorganisms to supply the unpurified multi-copper oxidases laccase and copper efflux oxidases at a biofuel cell cathode. Bioresour Technol 158:23-238. https://doi.org/10.1016/j.biort ech.2014.02.038

Savizi ISP, Kariminia H-R, Bakhshian S (2012) Simultaneous decolorization and bioelectricity generation in a dual chamber microbial fuel cell using electropolymerized-enzymatic cathode. Environ Sci Technol 46:6584-6593. https://doi.org/10.1021/es300367h

Schaetzle O, Barrière F, Schröder U (2009) An improved microbial fuel cell with laccase as the oxygen reduction catalyst. Energy Environ Sci 2:96-99. https://doi.org/10.1039/b815331k 
Sharma V, Kundu PP (2010) Biocatalysts in microbial fuel cells. Enzyme Microb Technol 47:179-188. https://doi.org/10.1016/j. enzmictec.2010.07.001

Shukla S, Oturan MA (2015) Dye removal using electrochemistry and semiconductor oxide nanotubes. Environ Chem Lett 13(2):157172. https://doi.org/10.1007/s10311-015-0501-y

Sonawane JP, Marsili E, Ghosh PC (2014) Treatment of domestic and distillery wastewater in high surface microbial fuel cells. Int $\mathrm{J}$ Hydrog Energy 39:21819-21827. https://doi.org/10.1016/j.ijhyd ene.2014.07.085

Strack G, Luckarift HR, Sizemore SR, Nichols RK, Farrington KE, Wu PK, Atanassov P, Biffinger JC, Johnson GR (2013) Power generation from a hybrid biological fuel cell in seawater. Bioresour Technol 128:222-228. https://doi.org/10.1016/j.biortech.2012.10.104

Sultan M (2017) Polyurethane for removal of organic dyes from textile wastewater. Environ Chem Lett 15:347-366. https://doi. org/10.1007/s10311-016-0597-8

Sun J, Bi Z, Hou B, Cao Y-Q, Hu Y-Y (2011) Further treatment of decolorization liquid of azo dye coupled with increased power production using microbial fuel cell equipped with an aerobic biocathode. Water Res 45:283-291. https://doi.org/10.1016/j. watres.2010.07.059

Tarkwa J-B, Oturan N, Acayanka E, Laminsi S, Oturan MA (2018) Photo-Fenton oxidation of Orange $\mathrm{G}$ azo dye: process optimization and mineralization mechanism. Environ Chem Lett. https:// doi.org/10.1007/s10311-018-0773-0

Téllez-Téllez M, Fernández FJ, Montiel-González AM, Sánchez C, Díaz-Godínez G (2008) Growth and laccase production by Pleurotus ostreatus in submerged and solid-state fermentation. Appl Microbiol Biotechnol 81(4):675. https://doi.org/10.1007/s0025 3-008-1628-6

Varghese AG, Paul SA, Latha MS (2018) Remediation of heavy metals and dyes from wastewater using cellulose-based adsorbents. Environ Chem Lett 9:1-11. https://doi.org/10.1007/s10311-01800843-z

Vats A, Mishra S (2018) Identification and evaluation of bioremediation potential of laccase isoforms produced by Cyathus bulleri on wheat bran. J Hazard Mater 344:466-479. https://doi. org/10.1016/j.jhazmat.2017.10.043

Wang N, Chu Y, Wu F, Zhao Z, Xu X (2017) Decolorization and degradation of Congo red by a newly isolated white rot fungus, Ceriporia lacerata, from decayed mulberry branches. Int Biodeterior Biodegrad 117:236-244. https://doi.org/10.1016/j.ibiod .2016.12.015

Wang Y, Chen Y, Wen Q (2018) Microbial fuel cells: enhancement with a polyaniline/carbon felt capacitive bioanode and reduction of $\mathrm{Cr}(\mathrm{VI})$ using the intermittent operation. Environ Chem Lett 16:319-326. https://doi.org/10.1007/s10311-017-0678-3

Watson VJ, Delgado CD, Logan BE (2013) Influence of chemical and physical properties of activated carbon powders on oxygen reduction and microbial fuel cell performance. Environ Sci Technol 47:6704-6710. https://doi.org/10.1021/es401722j

Wu C, Liu X-W, Li W-W, Sheng G-P, Zang G-L, Cheng Y-Y, Shen N, Yang Y-P, Yu H-Q (2012) A white-rot fungus is used as a biocathode to improve electricity production of a microbial fuel cell. Appl Energy 98:594-596. https://doi.org/10.1016/j.apene rgy.2012.02.058

Yang J, Lin Q, Ng TB, Ye X, Lin J (2014) Purification and characterization of a novel laccase from Cerrena sp. HYB07 with dye decolorizing ability. PLoS ONE 9(10):e110834. https://doi. org/10.1371/journal.pone.0110834

Zhang F, Merrill MD, Tokash JC, Saito T, Cheng S, Hickner MA, Logan BE (2011) Mesh optimization for microbial fuel cell cathodes constructed around stainless steel mesh current collectors. J Power Sources 196:1097-1102. https://doi.org/10.1016/j.jpows our.2010.08.011

Publisher's Note Springer Nature remains neutral with regard to jurisdictional claims in published maps and institutional affiliations. 